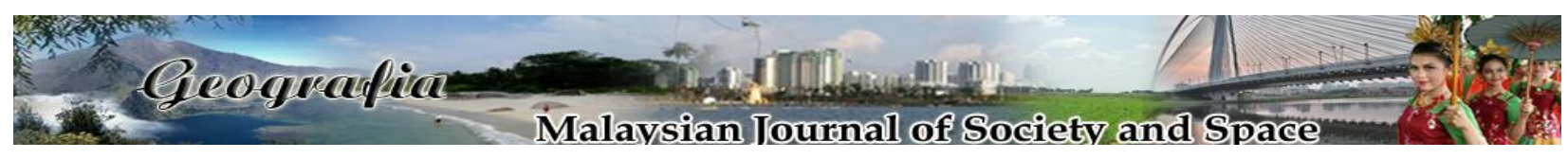

\title{
Kaedah tradisional dalam penghasilan beras oleh etnik Rungus
}

\author{
Johan Johnes ${ }^{1}$, Rosmiza M.Z. ${ }^{2}$, Jabil Mapjabil $^{1}$ \\ ${ }^{1}$ Institut Kajian Orang Asal Borneo, Universiti Malaysia Sabah \\ ${ }^{2}$ Program Geografi, Pusat Pembangunan, Sosial dan Persekitaran, Fakulti Sains Sosial dan Kemanusiaan, \\ Universiti Kebangsaan Malaysia \\ Correspondence: Johan Johnes (email: johanjohnes28@gmail.com)
}

Received: 16 April 2019; Accepted: 14 August 2019; Published: 22 August 2019

\begin{abstract}
Abstrak
Pertanian secara konvensional yang bercirikan kaedah tradisional amalan daripada nenek moyang sehingga kini masih diamalkan dan menggambarkan kearifan tempatan komuniti orang asal di beberapa daerah di Sabah. Tujuan utama kajian ini dilakukan adalah untuk mengenal pasti kaedah tradisional yang digunakan oleh etnik Rungus dalam penghasilan beras di daerah Pitas, Sabah. Selain itu, kajian turut meneliti elemen kearifan tempatan yang dimiliki oleh etnik Rungus dalam penghasilan beras di daerah ini. Kaedah kajian yang digunakan dalam kajian ini adalah kaedah kualitatif menggunakan kaedah temu bual dan pemerhatian yang ditafsir menggunakan transkrip verbatim dan analisis deskriptif. Hasil kajian yang diperoleh adalah berkaitan kaedah penghasilan beras secara tradisional dalam etnik Rungus di Kampung Kibulu, Pitas. Antara proses secara berperingkat tersebut adalah proses mongogis/mongulok, mongogoui/monidang, proses monutu/mongogiling, mangatap dan moniri. Antara ilmu kearifan tempatan yang menarik dalam penghasilan beras oleh kumpulan etnik ini adalah berkenaan penggunaan alat dan kaedah pertanian yang unik dan mempunyai ciri tersendiri seperti penggunaan linggaman dalam proses menuai padi serta kaedah mengasingkan padi daripada sekam padi yang begitu unik dengan menggunakan bahan-bahan terpakai. Ilmu kearifan tempatan yang digunakan dalam penghasilan beras dalam etnik Rungus di kawasan kajian amat berguna sebagai ilmu pertanian manual sekiranya penggunaan teknologi seperti kilang padi mengalami kerosakan ataupun tidak beroperasi. Kajian ini juga dapat membantu dalam mengekalkan warisan kaedah tradisional penghasilan beras oleh etnik Rungus supaya dapat dipelajari oleh generasi akan datang.
\end{abstract}

Kata kunci: etnik Rungus, kaedah tradisional, kearifan tempatan, komuniti orang asal, penghasilan beras, pertanian 


\title{
Traditional methods in rice production by the Rungus ethnic
}

\begin{abstract}
Conventional agriculture characterized by the traditional methods of their ancestors, which reflects the local knowledge of the indigenous peoples, is still practiced in several districts in Sabah. The main purpose of this study was to identify the traditional methods used by the Rungus ethnic in rice production in the Pitas district of Sabah. Besides, the study also examines the element of local knowledge owned by the Rungus ethnic in producing rice in this area. The research method used in this study was a qualitative method using interview and interpretation observation using verbatim transcript and descriptive analysis. The results of the study were about traditional rice production methods in the Rungus ethnic in Kampung Kibulu, Pitas. Among the stages in the rice production are the process of mongogis/mongulok, mongogoui/monidang, process of monutu/mongogiling, mangatap and moniri. Among the interesting local knowledge of rice production by the ethnic is the use of unique tools and methods of farming and has its own characteristics such as the use of linggaman in the process of paddy harvesting and the unique method of separating rice from the rice husk by using re-used materials. The local knowledge applied in rice production in the Rungus ethnic in the study area is a useful manual agricultural knowledge, in the event if the use of technology such as rice mills were damaged or inoperable. Finally, this study helps in preserving the traditional methods of rice production by the Rungus ethnic and to be shared with and learned by future generations.
\end{abstract}

Keywords: Rungus ethnic, traditional methods, local knowledge, indigenous peoples, rice production, agriculture, Pitas, Sabah

\section{Pengenalan}

Penghasilan beras secara tradisional dalam setiap kumpulan etnik yang terdapat di Sabah mempunyai keunikan dan caranya yang tersendiri berdasarkan kemahiran dan sumber yang terdapat di tempat mereka. Namun demikian, akibat daripada perubahan zaman dan peningkatan dalam penggunaan mesin sebagai alat ganti dalam pekerjaan harian manusia, kaedah tradisional dalam menghasilkan beras misalnya pada hari ini semakin dilupakan dan hampir luput ditelan zaman. Dalam Dasar Pertanian Malaysia Ke-3, dicatatkan bahawa sistem pertanian baharu di negara-negara membangun selalunya dianggap sebagai pertanian komersial (bukan untuk tujuan sara diri) yang menggunakan teknologi canggih dalam penghasilan dan pengeluarannya. Antara produk teknologi pertanian baharu tersebut adalah penggunaan baja kimia, racun serangga dan penggunaan jentolak khas dalam mengekstrak hasil pertanian sebelum dipasarkan.

Menurut Halib (2004), teknologi yang digunakan ini dipanggil sebagai input yang diusahakan melalui proses penyelidikan dan pembangunan (R\&D) yang akhirnya akan membantu dalam menghasilkan baka tanaman yang lebih baik dan seterusnya membantu dalam peningkatan hasil tanaman dan ekonomi para petani. Oleh hal yang demikian, kerancakan penggunaan teknologi dalam pertanian akhirnya memberikan kesan kepada kurangnya amalan tradisional masyarakat pribumi terutamanya di Sabah dalam menghasilkan keperluan makanan harian mereka dalam sektor pertanian. 
Kaedah tradisional penghasilan beras dalam pertanian padi sememangnya menghasilkan produktiviti yang rendah. Produktiviti yang rendah dalam aktiviti pertanian padi di negeri Sabah sering dikaitkan dengan amalan petani yang menggunakan teknologi tempatan yang kurang efisen (Paul, 1997). Namun, perkara ini amat berguna sebagai ilmu kearifan tempatan bagi penduduk yang terpinggir daripada arus teknologi dan terpaksa menggunakan kaedah tradisional untuk meneruskan kehidupan. Kekangan daripada kemasukan teknologi ke satu-satu petempatan di kawasan pedalaman yang sukar untuk dicapai turut menguatkan pendirian kaedah secara tradisional ini harus dikekalkan dan dipelajari. Oleh itu, kajian ini adalah bertujuan untuk mengetengahkan kaedah tradisional dan sekali gus meneliti setiap proses dalam penghasilan beras oleh komuniti etnik Rungus di daerah Pitas, Sabah.

\section{Kajian literatur}

\section{Pertanian, kearifan tempatan dan etnik Rungus}

Pertanian adalah suatu bentuk proses pengeluaran yang dikhaskan bagi mana-mana hasil daripada tanaman ataupun ternakan haiwan (Mosher, 1966). Menurut Mohammad Shukri (2011), pertanian merupakan sektor yang mampu menjana pendapatan negara dan penting dalam ekonomi sesebuah negara. Di Malaysia, sektor pertanian ini kebiasaannya hanya dipelopori oleh para petani secara kecil-kecilan sahaja dan kurang diminati oleh segolongan besar rakyatnya (Ashriq, 2012). Jabil et al. (2018) menyatakan bahawa sektor pertanian merupakan pemangkin utama kepada keutuhan sosioekonomi penduduk di luar bandar, selain melibatkan impak ke atas alam sekitar. Oleh itu, sektor pertanian perlu memaksimumkan penggunaan sumber di peringkat lokal, di samping mengintegrasikan keseluruhan rantaian nilai dengan sektor ekonomi lain. Sektor pertanian merupakan enjin utama dalam meningkatkan ekonomi komuniti luar bandar di kebanyakan negara (Kumar et al., 2015).

Menurut Adlina et al. (2013), kearifan tempatan adalah suatu bentuk kesinambungan ilmu yang diwarisi daripada satu bangsa yang asalnya daripada ilmu pengetahuan generasi terdahulu. Kearifan tempatan atau pengetahuan tradisional merujuk kepada pengetahuan yang terkumpul, bersifat kompleks dari segi amalan dan persembahan serta dikembangkan oleh individu yang mempunyai sejarah pengalaman yang panjang berdasarkan interaksi dengan alam semula jadi. Kepercayaan dan amalan yang diwarisi sejak turun-temurun merupakan kearifan tempatan petani luar bandar dalam melestarikan alam (Minah, 2018). Kearifan tempatan yang diwarisi sejak turun-temurun tersebut masih dikekalkan oleh sebilangan kecil petani luar bandar, terutama mereka yang kurang mendapat pendedahan terhadap teknologi ataupun tidak mampu membeli peralatan moden. Menurut Alidri (2016), kearifan tempatan dibangunkan dan berkembang secara spontan dalam masyarakat atau zaman tertentu. Warren dan Rajesakaran (1993), menegaskan kearifan tempatan merujuk kepada sekumpulan maklumat, petunjuk nasihat atau serangkai ilmu untuk strategi kehidupan serta menjadi alat untuk kelangsungan dan kedinamikan sesuatu bangsa.

Etnik Rungus majoritinya terdapat di bahagian utara negeri Sabah. Dua pertiga daripada jumlah masyarakat Rungus yang terdapat di bahagian utara negeri ini terdapat di daerah Kudat dan selebihnya di daerah Pitas, Kota Marudu dan lain-lain. Menurut Paul (1997), nama Rungus yang digunakan sebagai panggilan kepada keseluruhan masyarakat Rungus pada hari ini adalah berasal daripada nama seorang individu. Si Rungus telah membina sebuah rumah dan tinggal di 
sebuah tanjung berhampiran pekan Kudat sebelum kedatangan penjajah (sebelum tahun 1881). Nama Rungus ini akhirnya digunakan oleh etnik lain seperti Iranun, Bajau dan Suluk yang tinggal di sekitar pekan Kudat sebagai panggilan kepada orang lain yang mempunyai persamaan dengan si Rungus. Akhirnya, panggilan "Rungus" tersebut digunakan sebagai nama rasmi bagi merujuk kepada etnik Rungus yang ada pada hari ini. Antara aktiviti ekonomi sara hidup etnik Rungus adalah dengan bertani. Antara produk pertanian tersebut ialah tanaman sayur-sayuran, jagung, ubi, pisang buah-buahan dan menternak haiwan. Pada hari ini terdapat juga etnik yang bekerja di sektor kerajaan dan swasta.

\section{Kaedah tradisional dalam pertanian}

Terdapat banyak kajian yang berfokus kepada kaedah penghasilan output pertanian terutamanya dalam pengeluaran hasil padi. Menurut Maine dan Yusten (2010), pertanian di kampung mengalami perubahan akibat perkembangan teknologi baharu dalam pertanian. Proses penanaman dan penuaian hasil tanaman menggunakan kaedah tradisional semakin kurang kerana adanya kemudahan jentera dalam pertanian yang mampu mempercepat kerja dan menjimatkan masa petani. Walau bagaimanapun, penggunaan teknologi baru dalam pertanian ini mempunyai had kegunaannya yang tersendiri dan sekiranya gagal berfungi, berkemungkinan segelintir petani akan kembali kepada kaedah tradisional untuk menjalankan aktiviti pertanian mereka.

Sebagai contoh, Rahimah (1986) menyatakan bahawa penanaman padi dua kali setahun tidak dapat dijalankan di Krian, Perak kerana ketidakcekapan sistem pengairan dan saliran di kawasan itu. Penggunaan jentera seperti kabota dan sebagainya tidak boleh digunakan di semua tempat kerana jenis tanah yang berbeza. Akhirnya, petani kembali semula kepada penggunaan tajak untuk menajak tanah mereka. Situasi ini turut berlaku bagi proses penuaian padi dan penghasilan beras. Sekiranya teknologi baharu yang digunakan rosak atau tidak mampu menjalankan fungsinya, maka kaedah tradisional akan digunakan oleh para petani untuk menjalankan rutin bertani mereka. Perkara yang sama turut berlaku di Utara Iran yang mana produktiviti pertanian padi terbatas kerana adanya gangguan saliran air untuk tujuan pertanian (Darzi-Naftchali \& Ritzema, 2018). Namun, pengurusan bekalan air "sub-surface” di Iran telah berjaya mengatasi masalah air yang berlaku dan sekali gus meningkatkan produktiviti tanaman padi di negera tersebut.

Kaedah tradisional dalam pertanian sering dikaitkan dengan kearifan tempatan yang dimiliki oleh sesebuah etnik tersebut. Menurut Raden et al. (2011), kearifan tempatan merupakan gagasan dan pengetahuan tradisional suatu masyarakat yang telah menjadi panduan dalam berperilaku. Kearifan tempatan telah diamalkan secara turun-temurun bagi memenuhi keperluan masyarakat kerana memainkan peranan sebagai alat pelestarian sumber alam dan manusia, pengekalan adat dan budaya serta bermanfaat untuk melanjutkan kehidupan. Di Sabah, masyarakat Kadazandusun telah lama mengamalkan kearifan tempatan ini dalam kehidupan mereka khususnya dalam pertanian serta pemeliharaan dan pemuliharaan alam sekitar (Donney \& Norjietta, 2018).

Appell (1986), menyatakan bahawa masyarakat Rungus merupakan etnik yang amat handal dalam pertanian. Kehebatan ilmu pertanian oleh etnik ini adalah antara yang terbaik di Pulau Borneo. Ilmu pertanian oleh etnik Rungus dikatakan melangkaui ilmu pertanian yang ada pada etnik Iban dan beberapa lagi kumpulan etnik yang diketahuinya pada ketika itu. Hasil pertanian utama masyarakat Rungus ialah padi bukit yang ditanam di tagad (Paul, 1997). Terdapat beberapa pendapat yang menggambarkan ilmu menanam padi dalam etnik Rungus. Menurut Appell (1972), ilmu menanam padi oleh etnik Rungus telah diajarkan oleh mubaligh Kristian 
yang pernah berkhidmat di Hong Kong dan mempunyai pengetahuan tentang penananam sawah padi di sana. Namun demikian, pada tahun 1986, Appell turut menyatakan bahawa masyarakat Rungus mempelajari teknik menanam padi daripada etnik dusun di daerah Kota Belud kira-kira 60 tahun dahulu pada waktu itu.

Menurut Bahauddin et al. (2015), masyarakat etnik Rungus kebanyakannya ialah petani. Golongan wanita dalam etnik ini cukup terkenal dengan kemahiran membuat hasil tangan mereka (seperti membuat pakaian tradisional dan pelbagai jenis kraf tangan). Etnik ini turut memaparkan ikatan yang sangat rapat antara satu sama lain dengan adanya penglibatan semua ahli masyarakat dalam sesuatu perkara yang dilakukan (Pengiran Bagul, 2005). Etnik Rungus boleh dikatakan sebagai salah satu kumpulan etnik yang paling tradisional di kepulauan Borneo (Bahauddin et al., 2015). Kehidupan etnik Rungus begitu sinonim dengan kemahiran mereka dalam pertanian padi bukit. Bermula daripada proses memilih kawasan penanaman padi, pembersihan bukit, menanam padi di bukit, menjaga padi tersebut sehinggalah menuai hasil padi merupakan antara kepakaran etnik ini dalam pertanian tradisional.

Oleh itu, kaedah pertanian tradisional yang diwarisi dalam etnik Rungus secara tidak langsung boleh dikatakan sebagai ilmu pertanian yang amat penting untuk diperlihatkan sebagai satu bukti bahawa kaedah ini merupakan kearifan tempatan masyarakat Rungus yang terdahulu sebagai cara untuk meneruskan kehidupan. Penelitian cara penghasilan beras secara tradisional di Kampung Kibulu, Pitas ini amat penting kerana kebanyakan kampung dan daerah pengusaha padi di Sabah sudah menggunakan teknologi dalam pertanian mereka.

\section{Metod dan kawasan kajian}

Kajian ini adalah berbentuk deskriptif yang bertujuan untuk menghuraikan makna dalam sesuatu perkara atau subjek kajian (Veal, 2017). Kajian ini menggunakan kaedah kualitatif, iaitu perolehan data melalui temu bual, pemerhatian dan foto di lapangan. Menurut Jasmi (2012), kajian kualitatif memberikan keterangan tentang sifat dan keadaan manusia dengan menggunakan pandangan umum tentang apa-apa tindakan sosial. Data yang diperoleh dianalisis dalam bentuk transkrip verbatim. Melalui transkrip verbatim, maklumat penting direkodkan mengikut kategori berdasarkan rakaman temu bual bersama informan. Akhirnya, maklumat yang diperoleh dibincangkan sebagai satu perdebatan berkenaan kaedah pertanian tradisional masyarakat Rungus dalam penghasilan beras di daerah Pitas.

Bahasa yang digunakan dalam temu bual adalah dalam Bahasa Rungus, transkrip verbatim yang dipaparkan dibahagian dapatan kajian adalah sudah diterjemah dalam Bahasa Melayu. Seramai lima orang informan dipilih berdasarkan mereka yang benar-benar masih mengamalkan penghasilan beras secara tradisional setiap kali musim menuai padi tiba. Hal ini turut didorong oleh faktor kematangan padi semasa kajian sedang dijalankan kerana petani yang terdapat di kawasan kajian menanam padi dalam tempoh masa yang berbeza-beza, maka tahap kematangan padi juga adalah berbeza-beza.

Kawasan kajian dijalankan di Kampung Kibulu, Pitas, Sabah. Kampung ini terletak di bahagian tengah daerah Pitas (Rajah 1). Kampung ini berkeluasan 2700 ekar dan mempunyai penduduk seramai 319 orang (Profil Kampung Kibulu, 2016). Majoriti penduduk yang tinggal di kampung ini adalah daripada etnik Rungus dan Dusun Kimaragang. Antara etnik lain yang terdapat di kampung ini adalah etnik Dusun Tindal dan beberapa penduduk daripada etnik lain yang menetap kerana berkahwin dengan orang tempatan di kampung ini. 


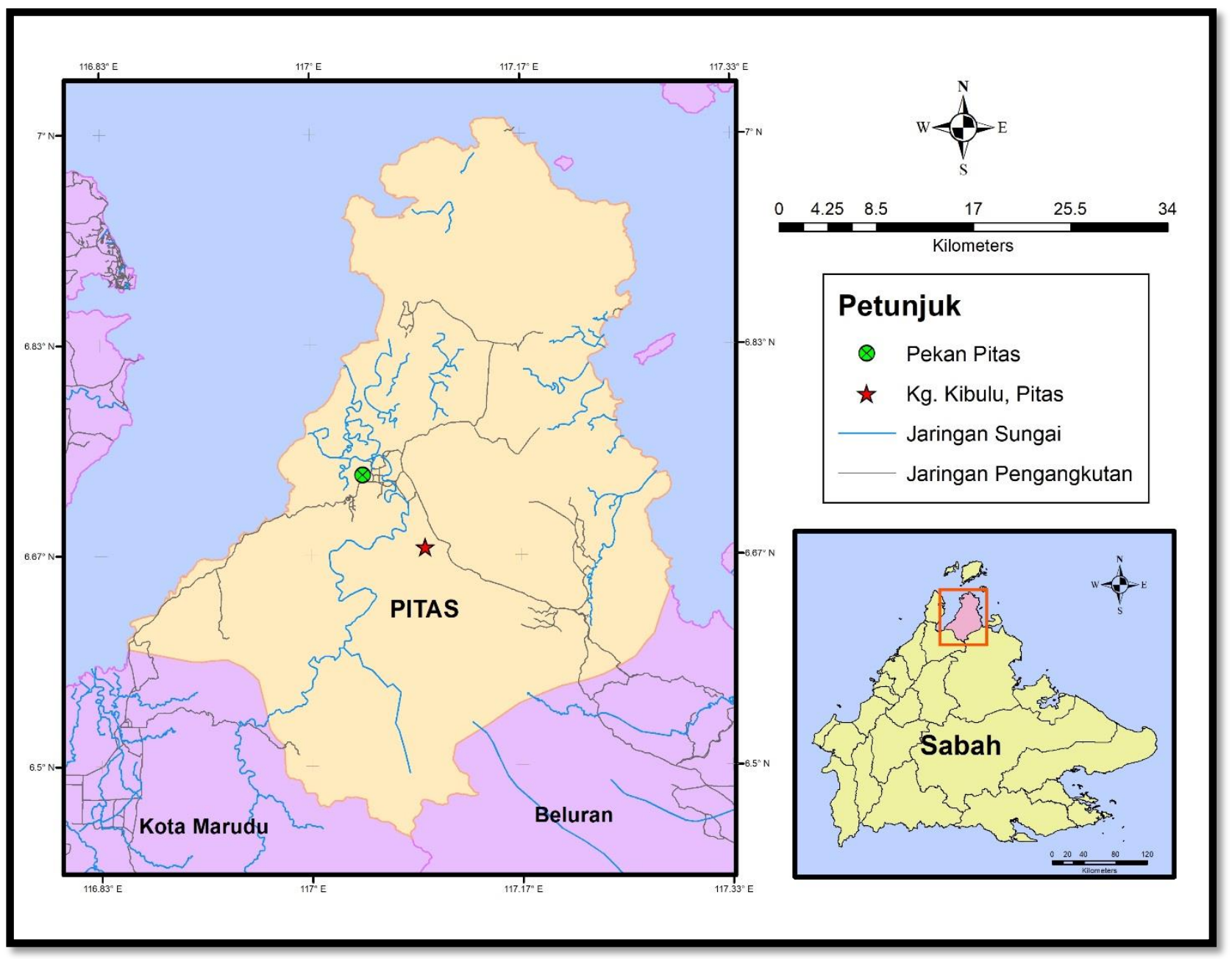

Rajah 1. Peta Kg. Kibulu, Pitas, Sabah

\section{Hasil kajian dan perbincangan}

Bahagian ini akan membincangkan berkenaan kaedah tradisional penghasilan beras oleh etnik Rungus dan kearifan tempatan yang dimiliki oleh mereka di kawasan kajian. Menurut Bahauddin et al. (2015), etnik Rungus amat terkenal dengan pengamalan budaya merentasi perubahan zaman dan masih mengamalkan gaya hidup tradisional masyarakat terdahulu pada masa kini. Secara tradisinya, sebelum proses penghasilan beras, masyarakat Rungus akan ke ladang padi huma (tagad) untuk mengetam padi (mongomot) menggunakan alat yang disebut sebagai linggaman. Linggaman diperbuat daripada kepingan besi yang kemudiannya dilekatkan kepada batang kayu yang kecil untuk dijadikan alat memisahkan padi daripada pokoknya. Rajah 2 menunjukkan peralatan tradisional yang digunakan oleh etnik Rungus untuk menuai padi, iaitu linggaman. 


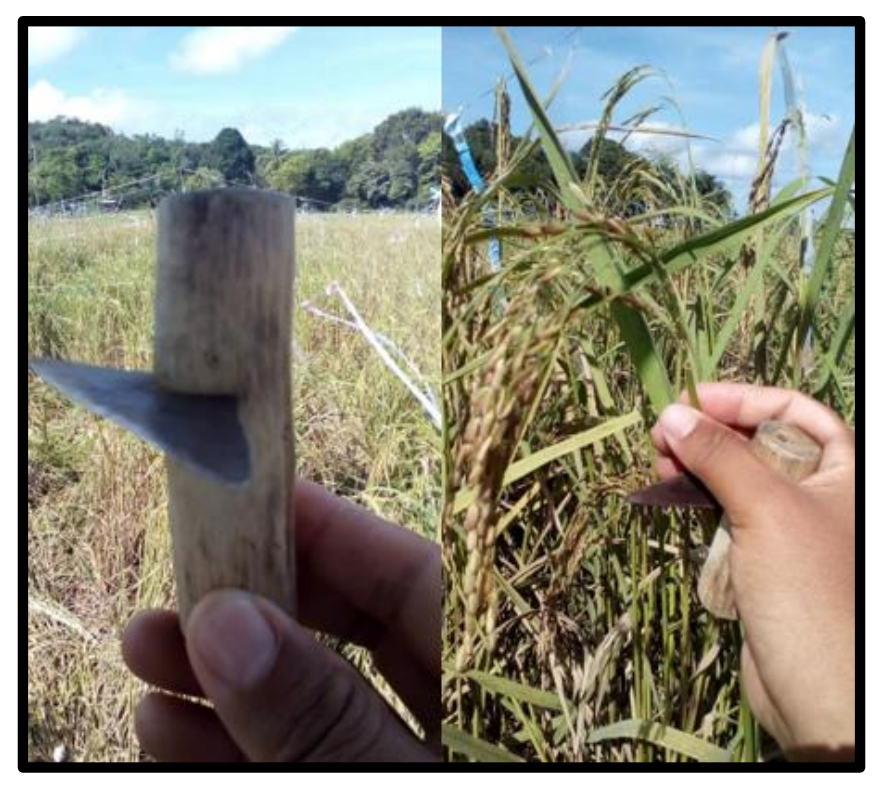

Rajah 2. Linggaman

Menurut informan yang ditemu bual, pembuatan linggaman memerlukan kearifan tempatannya yang tersendiri. Pembuatan linggaman ini adalah dihasilkan oleh petani sendiri secara tradisional. Hasil temu bual adalah seperti berikut:

“...Ya, Jika mahu buat linggaman, mesti menggunakan besi yang keras, kalau cuma menggunakan besi aluminium daripada tin minuman, ia tidak akan tahan lama dan mudah rosak".

“...Sayalah yang menghasilkan linggaman ini. Semua orang di kampung ini masingmasing menghasilkan linggaman mereka. Setakat ini saya belum pernah mendengar ada orang yang menjual linggaman di kampung ini”.

(Informan 1, 60 tahun).

Menurut informan, sebuah linggaman yang telah siap dihasilkan boleh bertahan melebih tiga tahun sekiranya disimpan di tempat yang betul dan tidak hilang.

"Kalau tidak hilang dan disimpan di tempat yang betul, linggaman ini boleh bertahan sehingga tiga tahun. Malahan, mungkin boleh tahan sehingga lima tahun".

(Informan 1, 60 tahun).

Penggunaan linggaman merupakan salah satu daripada pelbagai alat tradisional yang digunakan oleh petani untuk menuai padi secara tradisional. Dalam kajian oleh Hasan et al. (2019), di Bangledesh, kaedah manual dalam penuaian padi adalah dengan menggunakan sabit. Penggunaan sabit tersebut adalah seperti pada Rajah 3. 


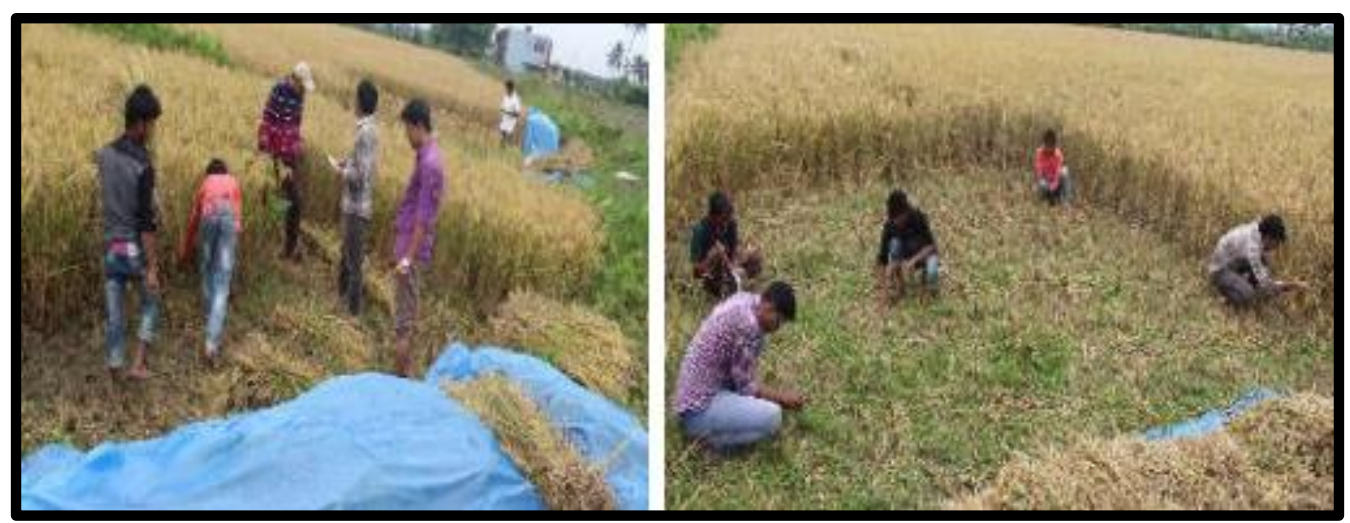

Sumber: Hasan et al., 2019

Rajah 3. Menuai padi secara manual menggunakan sabit

Menurut Ahmad Raflis et al. (2016), kadang kala output perlu melibatkan proses-proses tambahan sebelum produk benar-benar mencapai kualiti yang sesuai untuk dijual kepada pengguna akhir. Proses-proses ini berperanan sebagai panduan kepada penghasilan sesuatu output akhir yang ingin dihasilkan. Sehubungan itu, terdapat lima langkah atau proses dalam penghasilan beras secara tradisional selepas padi dituai dalam etnik Rungus di kawasan kajian. Proses tersebut boleh dilihat pada Rajah 4.

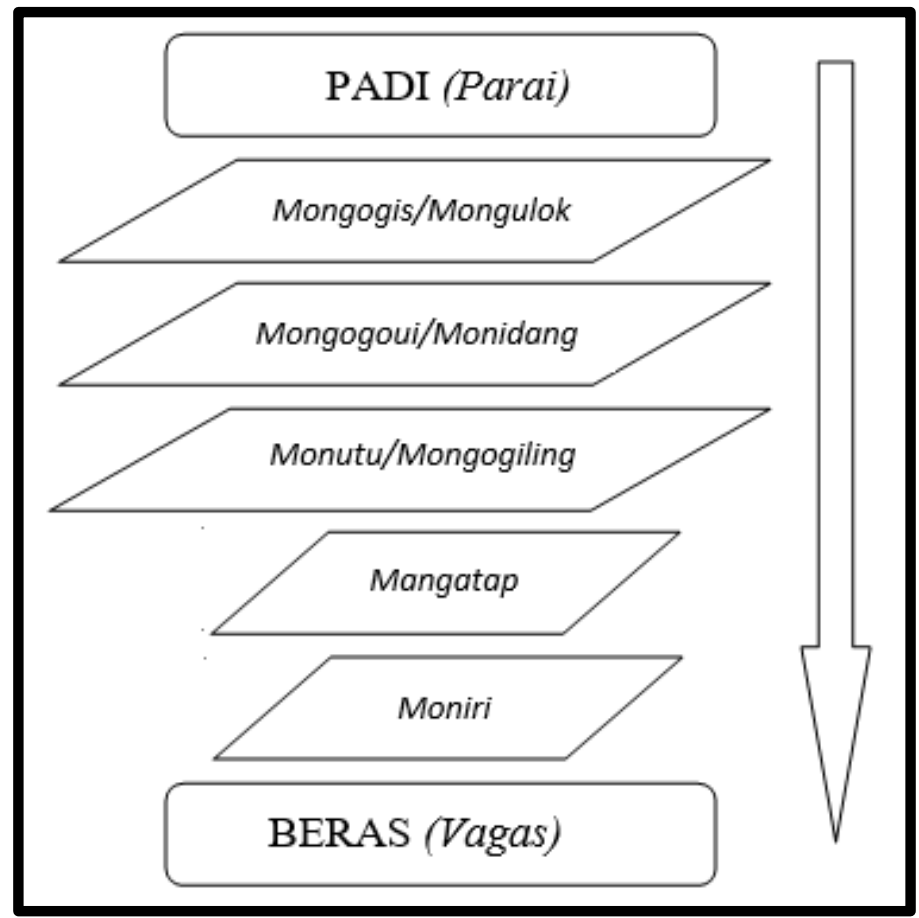

Sumber: Olahan pengkaji, 2019

Rajah 4. Proses penghasilan beras secara tradisional oleh etnik Rungus

Merujuk Rajah 4, selepas menuai padi proses penghasilan beras secara tradisional oleh etnik Rungus akan bermula. Proses pertama dalam penghasilan beras adalah proses mongogis diikuti proses mongogoui, monutu, mangatap dan moniri. 


\section{Proses mongogis}

Selepas selesai mongomot (menuai padi), padi yang telah dituai tadi akan melalui atau proses pengasingan daripada sekamnya (proses mongogis). Perkara ini adalah seperti yang dijelaskan oleh informan yang berikut;

“...Kalau sudah selesai menuai padi, kita perlu mengasingkan biji padi ini daripada sekamnya, proses ini disebut sebagai mongogis".

“...Proses mongogis dilakukan dengan menarik ke atas dan ke bawah pongogis (benda yang digunakan untuk mengasingkan padi daripada sekam) untuk memisahkan padi daripada sekamnya".

(Informan 4, 33 tahun)

Kearifan tempatan merupakan pengetahuan berdasarkan pengalaman masyarakat pribumi mengenai sumber-sumber yang digunakan untuk memastikan kelangsungan hidup mereka (Eva et al., 2018). Generasi demi generasi dalam komuniti telah membangunkan pengetahuan untuk meneruskan kehidupan sambil berintegrasi dengan alam sekitar dari semasa ke semasa. Dalam proses mongogis, petani akan menggunakan apa-apa sahaja bahan leper seperti cengkerang kerang, penutup botol, senduk makan dan sebagainya benda yang tidak tajam untuk memisahkan biji padi daripada sekam padi yang telah dituai. Perkara tersebut dinyatakan oleh informan seperti berikut;

“...Mesti menggunakan tutup gelen ataupun apa-apa barang leper yang tidak tajam”.

“...Tujuan tidak menggunakan benda tajam adalah supaya sekam padi tidak terputus semasa proses meleraikan padi dilakukan".

(Informan 4, 33 tahun)

Proses mongogis ini dilakukan bagi mengasingkan padi daripada sekam yang baru dituai sahaja. Proses ini dilakukan seperti dalam Rajah 5.

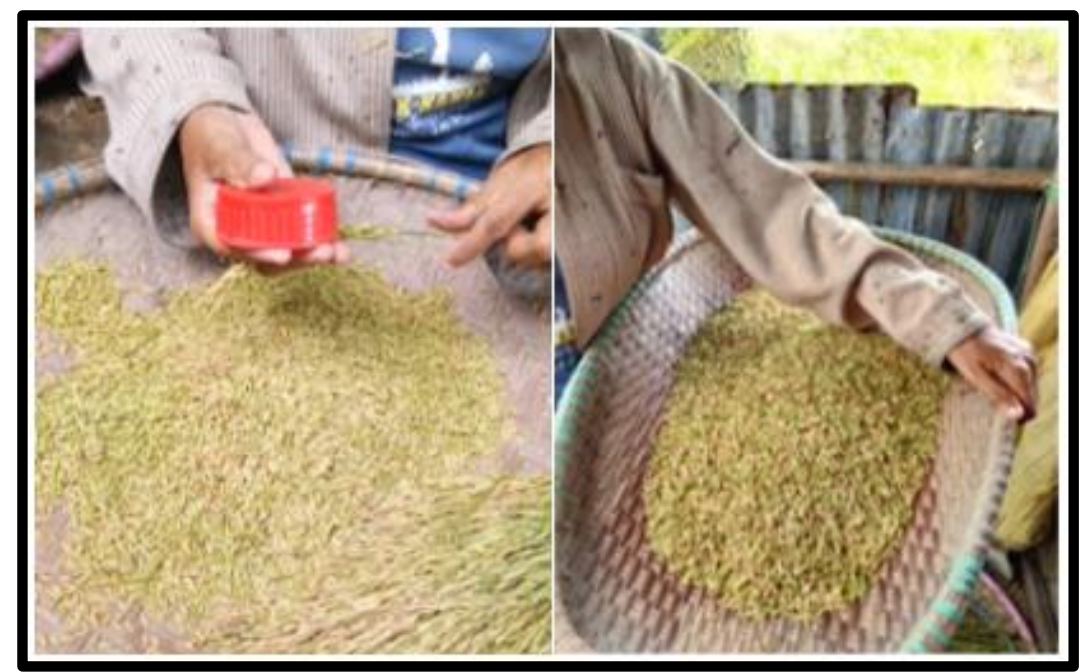

Rajah 5. Proses mongogis 


\section{Proses mongogoui/monidang}

Proses mongogoui sememangnya merupakan proses yang paling rumit untuk dilakukan dan biasanya dibuat oleh golongan wanita yang majoritinya lebih teliti dan lazimnya melakukan tugas di dapur dalam keluarga. Proses ini dilakukan bertujuan untuk menghilangkan getah yang terdapat di dalam padi. Menurut Informan 2, proses mongogoui dilakukan seperti berikut;

“...Betul, paling susah untuk dilakukan adalah proses mongogoui kerana perlu dijaga supaya menjadi”.

“...Kebiasaannya perempuan yang akan mongogoui, kerana kebiasaannya mereka yang akan melakukan kerja-kerja di dapur.. lagipun lebih teliti jika perempuan yang melakukan kerja ini".

(Informan 5, 35 tahun)

Dalam konteks kearifan tempatan, padi dimatangkan untuk menghilangkan getah dalam padi tersebut. Terdapat dua cara untuk mematangkan padi iaitu dengan menjemurnya di bawah sinaran matahari yang panas (monidang) ataupun memasak padi tersebut di dalam kuali (mongogoui) sehingga getah didalamnya kering. Oleh kerana mahu memendekkan masa dalam proses penghasilan beras semasa kajian dilakukan, informan memilih untuk mematangkan padi dengan cara mongogoui iaitu memasak padi di dalam kuali sehingga ia kering. Penggunaan kedua-dua kaedah ini adalah bergantung kepada keadaan semasa padi, proses mongogoui lebih banyak digunakan ketika pada baharu sahaja dituai. Manakala, padi yang sudah lama dituai biasanya akan menjalani proses monidang. Hal ini demikian kerana, padi yang baharu dituai mempunyai bau wangi yang biasanya lebih menarik selera untuk dimakan, sebaliknya padi yang sudah lama dituai tidak mempunyai bau wangi yang biasanya disebut sebagai "tavau ovongi dot parai vagu" atau bau wangi padi baharu oleh etnik Rungus.

Proses mongogoui memerlukan kepakaran dalam memastikan padi yang dimasak tidak hangus atau sebaliknya tidak matang. Terdapat dua keadaan padi yang dimasak yang boleh dirujuk untuk menentukan kematangan padi yang dimasak. Dua keadaan padi tersebut adalah proses pengeringan (lumonot) dan proses menjadi kuning (sumilou). Berikut merupakan hasil temu bual pengkaji bersama Informan 2 .

“...Ya, Mongogoui padi perlu dilakukan supaya getah padi cepat kering, sebenarnya boleh juga monidang (menjemur) padi tetapi lambat padi ini masak dan perlu dijaga sepanjang padi dijemur sebab akan ada ayam yang akan makan padi yang dijemur, lagi laju jika padi ini terus dimasak".

“...Ada dua cara untuk menentukan sama ada padi yang dimasak suda matang ataupun belum, Kalau padi itu baru dimasukkan ke dalam kuali, mesti sentiasa digaul sebab ia mudah hangus. Dalam masa lima minit barulah padi akan lumonot. Jadi jika padi sudah lumonot, akan ada padi yang meletup. Inilah yang menyebabkan beras baharu yang dihasilkan berbau wangi”. 
"...Lepas tu, kalau mahu siap sudah mongogoui, dapat dilihat sudah padi ini menguning. Jadi kalau semua padi yang dimasak sudah menguning, boleh diangkat suda padi tu daripada kuali”.

(Informan 2, 48 Tahun)

Seperti yang dinyatakan, proses mongogoui dan monidang ini akan digunakan mengikut usia padi, sekiranya padi baru dituai, adalah amat sesuai untuk melakukan proses mongogoui kerana dapat menambah bau wangi beras. Manakala, proses monidang pula lebih sesuai untuk padi yang sudah disimpan agak lama (lebih daripada satu bulan sehingga mencapai satu tahun) di dalam tempat penyimpanan padi (lingkut). Kepelbagaian dan keunikan dalam kaedah pertanian tradisional oleh etnik Rungus ini menguatkan lagi hujah oleh Appell (1986) yang menyatakan bahawa masyarakat Rungus adalah etnik yang amat handal dalam pertanian. Rajah 6 menunjukkan proses mongogoui, manakala Rajah 7 menunjukkan proses monidang.

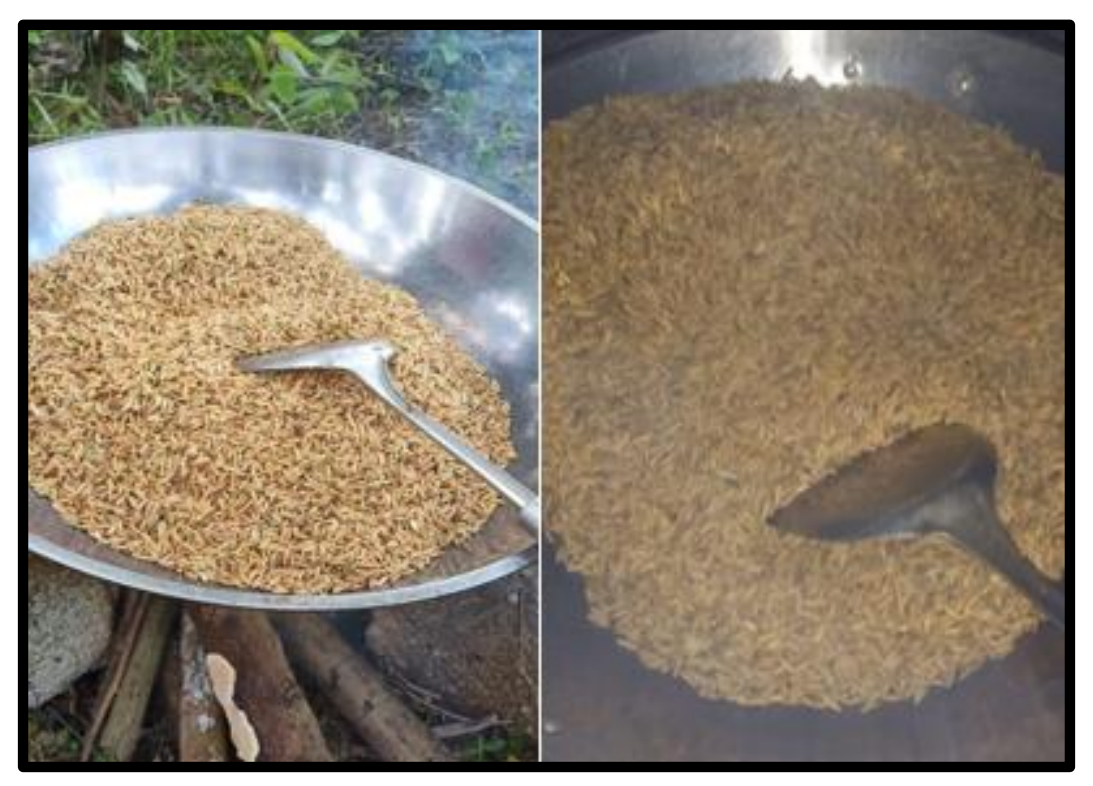

Rajah 6. Proses mongogoui 


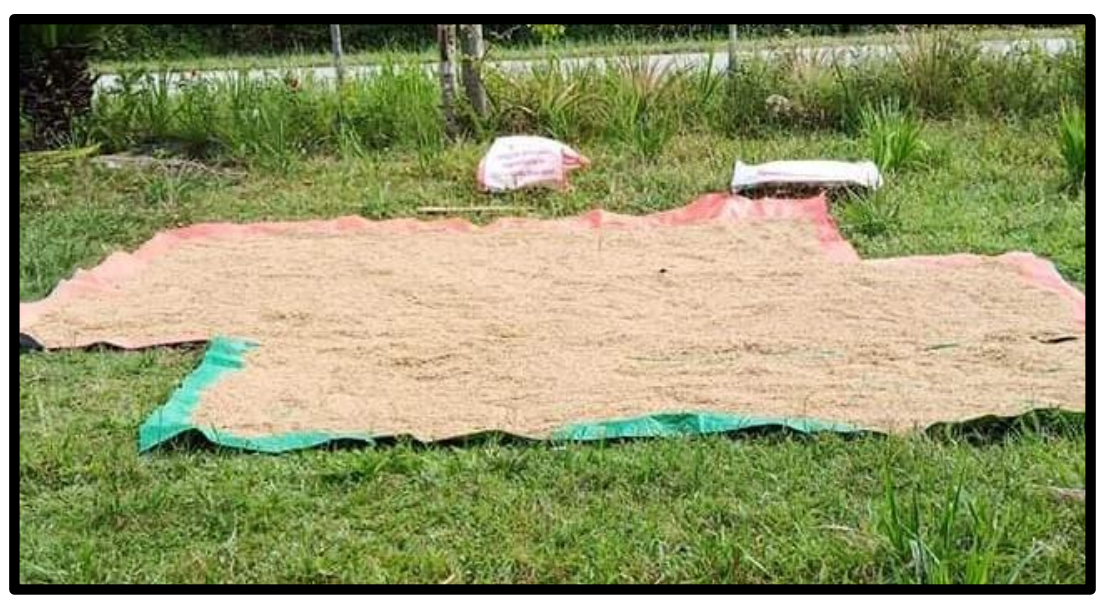

Rajah 7. Proses monidang

\section{Proses monutu/mongogiling}

Seterusnya, padi yang telah melalui proses mongogoui akan melalui proses menumbuk padi (monutu parai). Berbeza dengan proses mongogoui, kerja monutu ini biasanya akan dilakukan bersama oleh lelaki dan perempuan. Hal ini demikian kerana padi untuk memisahkan kulit padi, penumbuk padi (gohulo) digunakan. Goholu merupakan penumbuk lesung padi yang diperbuat daripada kayu dan agak berat. Oleh kerana sifat goholu yang berat, maka banyak tenaga diperlukan untuk mengangkat dan menumbuk padi yang sudah dimasukkan ke dalam lesung padi (tonsung). Oleh itu, tenaga lelaki diperlukan untuk menumbuk padi tersebut. Namun demikian, kerja ini juga dilakukan oleh golongan wanita yang sihat dan boleh mengangkat beban goholu yang berat. Proses monutu ini biasanya dilakukan oleh dua sehingga tiga atau empat orang. Semakin ramai orang yang terlibat, semakin cepat proses kulit padi tersebut untuk terbuka supaya padi yang dituai boleh menjadi beras. Hal ini demikian seperti yang disebutkan oleh Informan 3.

“...Kalau sudah selesai mongogoui, boleh sudah padi ini ditumbuk, kebiasaannya proses menumbuk padi dilakukan bersama-sama oleh lelaki dan perempuan”.

“...Dua, tiga atau empat orang kebiasaannya yang akan menumbuk padi. Semakin ramai orang, semakin cepat padi tersebut menjadi beras”.

(Informan 3, 28 tahun)

Menurut Neilson dan Spencer (2012), minat mempertahankan kearifan tempatan oleh masyarakat pribumi kian mendapat perhatian dan perjuangan daripada gerakan-gerakan yang membela hak masyarakat pribumi. Hal ini demikian kerana, kearifan tempatan yang dimiliki oleh penduduk tempatan merupakan sebuah manifestasi kemahiran asal penduduk yang harus diwarisi dan diketahui oleh genarasi akan datang di samping boleh dikomersialkan sebagai satu komponen dalam pembangungan dan pemasaran produk pelancongan luar bandar. Dalam konteks kearifan tempatan, kerja menumbuk padi ini sebenarnya adalah kerja menukarkan bentuk fizikal padi kepada beras. Proses ini dilakukan menggunakan lesung kayu dan penumbuk yang diperbuat daripada kayu. Selain itu, gilingan kayu juga boleh digunakan sekiranya tidak cukup orang untuk proses monutu. Masyarakat Rungus turut memanggil proses ini sebagai 
proses misaud ataupun mongohodok parai. Kebiasaannya, kerja ini akan dilakukan di ruang beranda rumah ataupun di halaman rumah. Padi akan dimasukkan ke dalam lesung kayu dan proses monutu dilakukan dengan menggunakan penumbuk kayu. Rajah 8 menunjukkan proses monutu dilakukan.

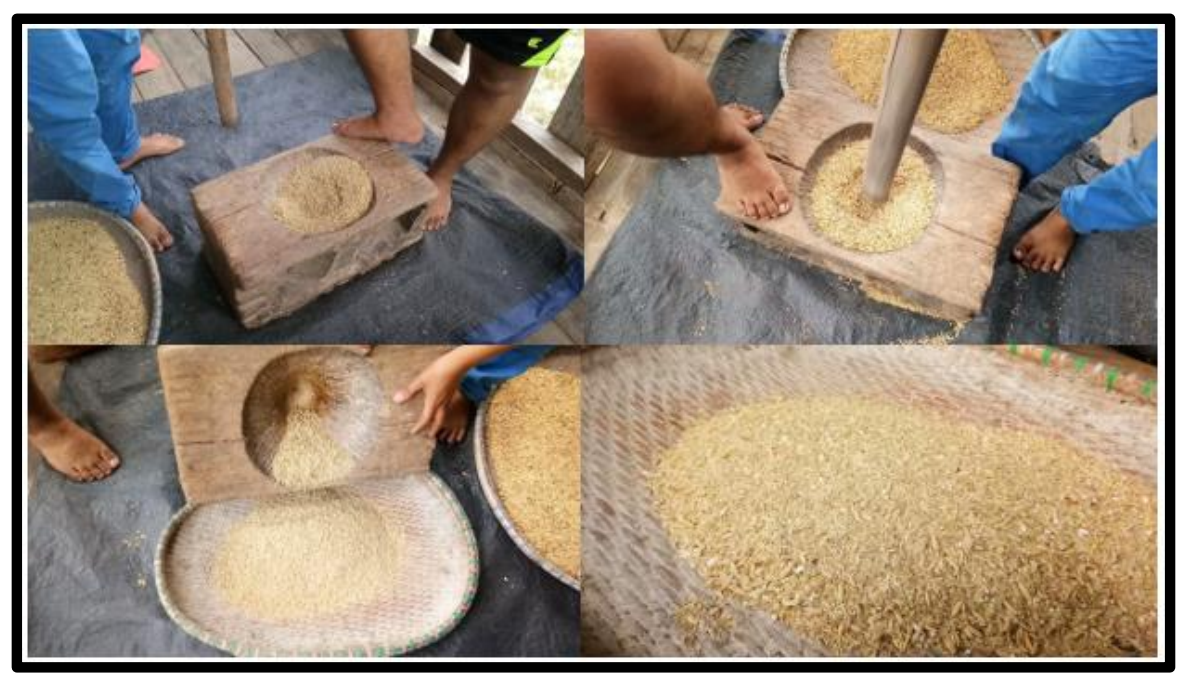

Rajah 8. Proses monutu

\section{Proses mangatap}

Selepas selesai proses monutu, beras akan dibersihkan melalui proses mangatap untuk mengasingkan kulit padi dan beras. Proses menampi atau mangatap ini lazimnya dilakukan oleh perempuan dengan menggunakan nyiru berbentuk bujur yang dipanggil sebagai rolibu dalam bahasa Rungus. Cara melakukan proses ini adalah dengan menghayunkan rolibu ke atas dan ke bawah sehingga kulit padi terkeluar daripada rolibu yang sedang digunakan. Proses mangatap dijelaskan seperti berikut;

“...Setelah siap menumbuk padi, beras yang terhasil akan ditampi bagi mengasingkan kulit padi daripada beras. Kebiasaannya golongan wanita yang melakukan kerja ini”.

“...Ya, mengggunakan rolibu untuk mangatap supaya cepat memisahkan kulit padi daripada beras.. selepas selesai mangatap, boleh sudah menampi untuk mengasingkan beras, kulit padi dan tombilod (dedak)".

“...Cara untuk menampi adalah dengan menghayunkan rolibu ke atas dan ke bawah, selepas itu barulah beras dapat diasingkan daripada kulit padi”.

(Informan 5, 35 tahun).

Proses mangatap ataupun menampi padi ini turut merupakan salah satu kearifan tempatan yang dimiliki oleh etnik Rungus yang terdapat di kawasan kajian. Di kawasan kajian, aktiviti pertanian diusahakan secara sema-rata oleh kedua-dua golongan lelaki dan perempuan. Golongan lelaki lebih banyak terlibat dalam proses awal pertanian seperti membajak sawah padi, memotong rumput dan membersihkan kawasan pertanian. Manakala, golongan wanita pula lebih 
banyak terlibat dalam proses menanam, menjaga padi, dan proses-proses menghasilkan pasi menjadi beras. Menurut Potter (1979), di Asia Tenggara dinyatakan bahawa wanita merupakan penyumbang tenaga buruh kepada pengeluaran tanaman. Dinyatakan bahawa wanita menyediakan lebih 90 peratus tenaga buruh untuk perusahaan padi (Potter, 1979). Hasil daripada padi yang telah ditumbuk, kulit padi dan beras terpisah. Oleh itu, proses mangatap ini dilakukan untuk mengasingkan kulit padi daripada beras. Rajah 9 menunjukkan cara proses ini dilakukan.

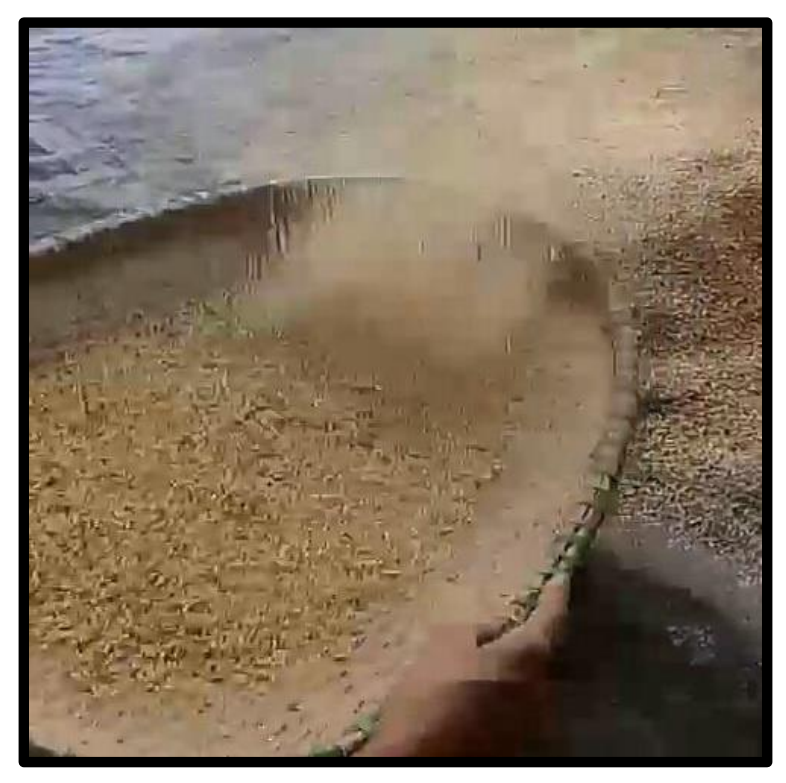

Rajah 9. Proses mangatap

\section{Proses moniri}

Seterusnya, terdapat pula proses mengasingkan beras dan padi yang masih mempunyai kulit selepas proses mangatap. Proses tersebut disebut sebagai proses moniri. Proses ini merupakan proses yang terakhir dalam menghasilkan beras secara tradisional oleh etnik Rungus yang terdapat di Kampung Kibulu, Pitas. Selepas proses ini, beras sudah bersedia untuk dicuci dan boleh dimasak untuk dimakan. Hal ini adalah seperti apa yang dikatakan oleh Informan 2;

“...Kalau sudah siap menampi, beras ini akan ditampi bagi mengasingkan padi daripada beras, susah juga mahu moniri ni, tak ramai sudah yang pandai moniri sekarang".

“...Cara untuk moniri adalah dengan mengayunkan ke kanan dan ke kiri rolibu supaya beras akan bergerak ke hadapan dan padi akan bergerak ke belakang”.

“...Semakin kurang orang yang pandai moniri sekarang, orang susah mahu belajar cara moniri, lagipun banyak sudah orang beli beras di kedai masa sekarang, sikit sudah yang menanam padi secara tradisional".

“...Ya! Inilah langkah terakhir dalam menghasilkan beras. Asingkan dulu baru boleh dimasak dan dimakan.”. 
(Informan 2, 48 tahun).

Rajah 10 menunjukkan proses moniri sedang dilakukan. Dalam konteks kearifan tempatan, melalui proses ini beras akan terkumpul di bahagian depan nyiru, manakala padi terkumpul di bahagian pangkal nyiru. Kerja untuk memisahkan padi dan beras akan menjadi lebih mudah. Proses ini merupakan proses yang terakhir sebelum beras boleh dimasak dan dimakan. Namun demikian, menurut informan jumlah individu yang boleh moniri semakin kurang. Hal ini demikian kerana, proses moniri merupakan satu proses yang amat sukar untuk dipelajari kerana ia melibatkan kiraan pukulan jari di bagiaan kiri dan kanan nyiru. Sekiranya tidak mempunyai kepakaran tersebut, padi dan beras tidak dapat diasingkan di atas nyiru. Tambahan lagi, sifat kebanyakan penduduk yang semakin bergantung kepada bekalan beras yang dibeli di kedai menyebabkan kaedah tradisional seperti ini semakin dilupakan. Ia seiring dengan dapatan oleh Habibah et al. (2017) yang menyatakan bahawa kepelbagaian ilmu kearifan tempatan semakin terancam dan kebanyakkan daripada kemahiran tersebut hanya dimiliki oleh golongan yang berusia sahaja.

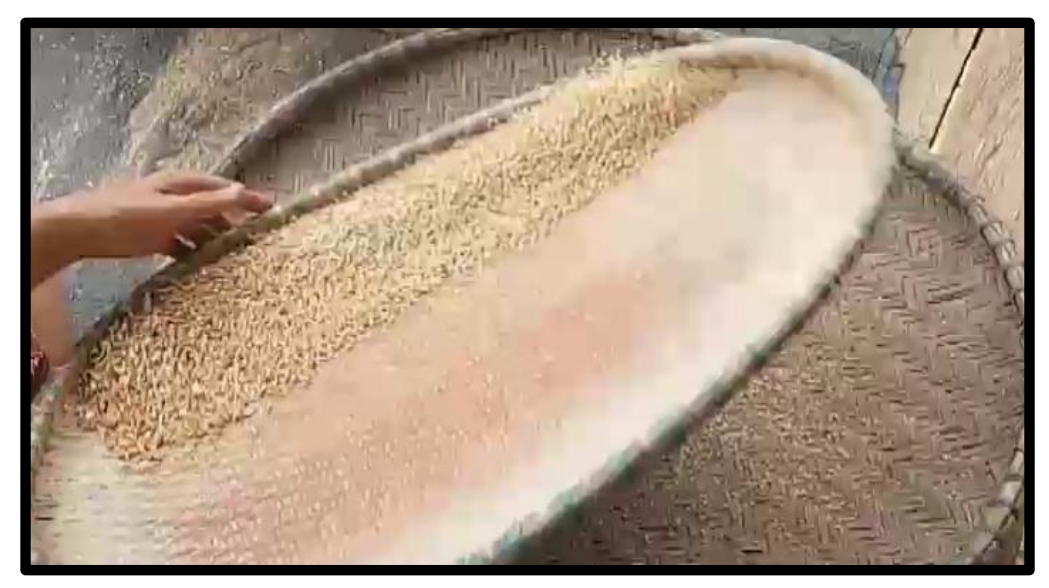

Rajah 10. Proses moniri

Akhirnya, beras dihasilkan setelah melalui proses mongogis, mongogoui, monutu, mangatap dan moniri. Proses ini dijangka mengambil masa selama hampir satu jam untuk lima kilogram beras dan bergantung kepada seberapa banyak padi yang ingin diproses menjadi beras. Oleh itu, amatlah penting untuk diperhatikan bahawa proses penghasilan beras dalam etnik Rungus di kawasan kajian mempunyai banyak elemen pertanian tradisional dan kearifan tempatan yang mana secara tidak langsung menggambarkan keunikan dan pengetahuan masyarakat Rungus yang begitu luas dalam menghasilkan beras walaupun dengan menggunakan kaedah tradisional tanpa bantuan teknologi moden. Jika diamati, kaedah tradisional dan ilmu kearifan tempatan dalam etnik Rungus yang terdapat di kawasan kajian boleh dikomersialkan sebagai satu bentuk aktiviti yang boleh menjana pendapatan selain daripada memenuhi keperluan harian.

Hasil daripada penelitian pengkaji, kecenderungan untuk bertani secara skala kecil dan kekangan kewangan untuk menguruskan pertanian moden menyebabkan masyarakat Rungus memilih hanya untuk melakukan pertanian sara hidup sahaja. Namun demikan, perubahan masa dan keperluan terhadap kewangan telah mendorong para petani untuk menjual lebihan hasil tanih mereka. Perkara ini mempunyai situasi yang sama seperti yang dinyatakan oleh Mohd Azlan et al. (2017) yang menyatakan bahawa para petani kecil keluar menjual lebihan hasil tani atau 
menjual tenaga mereka sebagai buruh upahan untuk meningkatkan pendapatan keluarga demi menampung keperluan-keperluan baru mereka.

\section{Kesimpulan}

Tuntasnya, kaedah tradisional dalam penghasilan beras yang terdapat di kawasan kajian amat penting untuk dikenal pasti sebagai bukti survival etnik Rungus yang terdapat di negeri Sabah. Penelitian terhadap proses-proses dalam menghasilkan beras oleh etnik ini secara tidak langsung memberikan kefahaman berkenaan elemen kearifan tempatan yang dimiliki oleh petani Rungus untuk meneruskan kehidupan mereka dalam sektor pertanian. Melalui kajian ini, turut dinyatakan bahawa semua alat teknologi moden dalam pertanian mempunyai keterbatasan dalam menjalankan fungsinya. Kekangan modal kewangan dan beberapa perkara yang tidak dapat dielakkan seperti jarak tapak pertanian yang jauh di kawasan pedalaman dan tiada akses jalan yang baik sekali gus mendorong penduduk di kawasan kajian untuk menggunakan kaedah tradisional dalam pertanian bagi penanaman padi dan penghasilan beras mereka. Tuntasnya, adalah satu keunikan untuk sesebuah etnik yang masih mempertahankan kearifan tempatan dalam pertanian padi di zaman moden kini. Oleh itu, warisan daripada nenek moyang berkenaan strategi pertanian tradisional ini perlulah dipelajari dan dikekalkan supaya boleh dinikmati oleh generasi akan datang.

\section{Rujukan}

Adlina Ab. Rahman, Othman, N., Ismail, S.R., Jawan, J.A., \& Ibrahim, N.N. (2013). Traditional knowledge and environmental conservation among indigenous people in Ranau, Sabah. Global Journal of Human-Social Science Research., 13(3), 5-11.

Ahmad Raflis Che Omar, Suraiya Ishak, Abd. Hair Awang, Mohd Yusof Hussain, Novel Lyndon, \& Abdullah Sanusi Othman. (2016). Orang tengah dalam rantaian pengeluaran pekebun kecil kelapa sawit di Malaysia: Satu penemuan awal dari Perak. GeografiaMalaysian Journal of Society and Space, 12(5), 161-170.

Alidri, A. (2016). Traditional wisdom in land use and resource management among the Lugbara of Uganda: A historical perspective. SAGE, 1-13.

Appell, G.N. (1972). Rungus Dusun ethnic groups of insular Southeast Asia. Vol. 1. In Lebar, F.M. (Ed.), Human relations area files. (pp. 150-163), New Haven.

Appell, G.N. (1986). Social anthropological research among the Rungus Dusun. A talk for the Sabah Society. 1-36.

Ashriq Fahmy Ahmad. (2012). Cabaran graduan usahawan tani. Retrieved from http://www.utusan.com.my

Bahauddin, A., Abdullah, A., \& Maliki, N.Z. (2015). The Rungus longhouse of Sabah, Malaysian Borneo - A dying architecture. SHS Web of Conferences, (18).

Darzi-Naftchali, A., \& Ritzema, H. (2018). Integrating irrigation and drainage management to sustain agriculture in northern Iran. Sustainability, 10(6), 1775.

Donney Fred Desmon, \& Norjietta Julita Taisin. (2018). Local Knowledge on Agriculture of Kadazandusun Community in Sabah. Malaysian Journal of Social Sciences and Humanities (MJSSH), 3(3), 122-130. 
Eva Kristin Larry Sait, Neilson Ilan Mersat, \& Swee Kiong Wong. (2018). Preliminary observations on indigenous knowledge and the uses of natural resources in Banting and Padawan. Akademika, 88(3). 33-42.

Habibah Ahmad, Asmilah Hani Mohamad, Hamzah Jusoh, Mastura Mahmud, Hazita Azman, Norngainy Mohd Tawil, Shamshubaridah Ramlee, Ruhaiza Abu Bakar, \& Amirah Muhammad Zin. (2017). Aset Pelancongan Luar Bandar dari Lensa Komuniti Lembah Beriah. Geografia-Malaysian Journal of Society and Space, 13(1), 87-100.

Halib, M. (2004). Peranan tanaman padi dalam pembangunan pertanian di Malaysia: Analisis sejarah dan kontemporari. Jati-Journal of Southeast Asian Studies, 9, 189-212.

Hasan, M.K., Ali, M.R., Saha, C.K., Alam, M.M., \& Hossain, M.M. (2019). Assessment of paddy harvesting practices of Southern Delta Region in Bangladesh. Progressive Agriculture, 30, 57-64.

Jabil Mapjabil, Rosmiza Mohd Zainol \& Norsuhana Abdul Hamid. (2018). Pertanian dan komuniti luar bandar. Penerbit UMS, Kota Kinabalu, Sabah.

Jasmi, K.A. (2012). Penyelidikan kualitatif dalam Sains Sosial. Kursus Penyelidikan Kualitatif, 1 (2012), 1-11.

Maine Suadik, \& Yusten Karulus. (2010). Teknologi, perubahan amalam pertanian dan isu rasionaliti masyarakat petani di Sabah. Malaysia. Sosiohumanika, 3(1), 41-51.

Minah Sintian. (2018). Kearifan lokal dalam pertanian sebagai mekanisma pelestarian alam sekitar luar bandar. Jabil Mapjabil, Rosmiza Mohd Zainol, Norsuhana Abdul Hamid (ed.). Pertanian dan komuniti luar bandar. Penerbit UMS, Kota Kinabalu, Sabah.

Mohammad Shukri Majalin. (2011). Menjadi usahawan tani yang berjaya. Selangor, Penerbitan Melur.

Mohd Azlan Abdullah, Rosmiza Mohd Zainol., Rosniza Aznie Che Rose., \& Amriah Buang. (2017). Mengungkap kelestarian pertanian kecil Melayu pada zaman penjajahan British. Geografia-Malaysian Journal of Society and Space, 5(3), 76-87.

Mosher. (1966). Getting agriculture moving. New York, Development Council, Inc.

Neilson Ilan Mersat \& Spencer Empading Sanggin. (2012). Migrasi, identiti dan kearifan tempatan: Kaum Iban di Sabah, Malaysia. Prosiding Simposium Bahasa dan Budaya Iban dan Folkor Malaysia, Fakulti Bahasa Komunikasi, UPSI.

Paul, P. (1997). Kemiskinan di kalangan kaum Rungus di daerah Kudat, Sabah (Phd dissertation). Retrieved from Universiti Malaya, Kuala Lumpur.

Pengiran Bagul, A.H.B. (2005). Community-based ecotourism development and local community participation. In Kaye Chon (Ed.), One earth one family: Travel \& tourism Serving a higher purpose (pp. 6). 3rd Global Summit on Peace through Tourism - Education Forum. Pattaya, Thailand, October 2-5.

Potter, S H. (1979). Family life in Northern Thai village: A study in the structural significance of women. Berkeley, Universiti of California Press.

Raden Cecep Eka Permana, Isman Pratama Nasution, \& Jajang Gunawijaya. (2011). Kearifan lokal tentang mitigasi bencana pada masyarakat Baduy. Makara, Sosial Humaniora, 15(1), 67-76.

Rahimah Abdul Aziz. (1986). Pepindahan teknologi ke sektor desa: Antara pelaksanaan dan keberkesanan. Akademika, 28, 1-16.

Veal, A.J. (2017). Research methods for leisure and tourism. Pearson, United Kingdom.

Warren D.M., \& Rajasekaran, B. (1993). Putting local knowledge to good use. International Agriculture Development, 13, 8-10. 